\title{
O SELF FICCIONAL DA LINGUAGEM
}

\author{
The fictional self of the language
}

\author{
Michel Euclides Bruschi ${ }^{a}$, Neuza Maria de Fátima Guareschi ${ }^{\mathrm{b}}$ \\ a Mestre em Psicologia Social e da Personalidade e doutorando em Psicologia na Pontifícia Universidade Católica do Rio Grande, \\ Bolsista CNPq do Sul, Porto Alegre, RS - Brasil, e-mail: micbeat@hotmail.com \\ b Professora e pesquisadora do Programa de Pós-Graduação em Psicologia da PUCRS, Ph.D. pela Universidade de Wisconsin/ \\ EUA e coordenadora do grupo de pesquisa Estudos Culturais e Modos de Subjetivação. Porto Alegre, RS - Brasil, e-mail: \\ nmguares@pucrs.br
}

\begin{abstract}
Resumo
Este artigo tem como objetivo mostrar e problematizar diferentes visões de linguagem e self que criticam aquelas que defendem a linguagem como fala e um self essencialista. Para isso, serão apresentadas duas propostas alternativas para se estudar o tema. A primeira é a concepção de linguagem como agenciamento e as idéias de Nikolas Rose sobre o conceito de dobra. A segunda é a perspectiva da linguagem como narrativa da virada narrativa e o conceito de self transacional de Jerome Bruner. Tanto Rose quanto Bruner propõem conceitos de self diferentes do essencialismo do Humanismo, da Hermenêutica e da Fenomenologia a partir de visões diferentes de linguagem. Esses autores procuram diferenciar suas idéias das propriedades subjetivantes da linguagem, evitando que a subjetividade seja considerada apenas uma operação lingüística. Propriedades subjetivantes da linguagem que são usadas por outras teorias para defender um self essencialista constituído no interior da fala, onde o agente humano seria o núcleo dessas atividades de produção de sentido. A importância de outras visões de linguagem e self, como as de Rose e Bruner, está principalmente em mostrar que estas questões da subjetividade não são apenas questões internas da linguagem e que, portanto, a reinvenção de nós mesmos não é só uma questão de semântica e sintática. Por fim, proporemos chamar o self que emerge das propriedades subjetivantes da linguagem de selfficcional, para que seja estudado como um discurso que nos subjetiva e não como um selfessencialista.
\end{abstract}

Palavras-chave: Self; Linguagem; Agenciamento; Dobra; Narrativa. 


\begin{abstract}
This article aims at showing and problematizing different views of language and self that have criticized those that advocate both language as speech and an essentialist self. To do so, two alternative proposals have been presented to study this subject. The first one is the conception of language as agency and the ideas by Nikolas Rose about the concept of fold. The second one is the perspective of language as narrative, according to the narrative turnover, and the concept of transactional self, according to Jerome Bruner. Both Rose and Bruner have proposed concepts of self that are different from the essentialism proposed by Humanism. Hermeneutics and Phenomenology, considering different views of language. Those authors have attempted to differentiate their ideas about the subjectification properties of language, thus avoiding that subjectivity is considered just as a linguistic operation. These subjectification properties of language have been used by other theories to advocate an essentialist self constituted within the speech, where the human agent would be the nucleus of meaning production activities. The importance of other views of language and self, such as those by Rose and Bruner, is mainly to show that subjectivities issues are not just internal issues in language and that, therefore, reinvention of ourselves is not only a matter of semantics and syntax. Finally, we propose that the self emerging from subjectivation properties of language is called fictional self, to be studied as a discourse that subjectifies us, rather than an essentialist self.
\end{abstract}

Keywords: Self; Language; Agency; Fold; Narrative.

\section{INTRODUÇÃO}

Este ensaio tem como objetivo mostrar e problematizar diferentes visões de linguagem e self $f^{1}$ que criticam aquelas que defendem a linguagem como fala e um self essencialista. Para isso, primeiro apresentaremos a concepção de linguagem como agenciamento e o pensamento de Nikolas Rose sobre o conceito de dobra. Posteriormente, apontaremos a diferença da perspectiva da linguagem como narrativa da virada narrativa de outras abordagens sobre este tema e as idéias de Jerome Bruner sobre o self transacional. Num último momento, faremos mais algumas reflexões sobre as questões discutidas por estes autores.

\section{LINGUAGEM COMO AGENCIAMENTO}

Para apresentar e discutir as suas idéias sobre self e linguagem, Rose (2001), no texto Inventando nosso eus, prefere primeiro mostrar algumas visões da qual a sua posição vai se afastar.
O autor critica os psicólogos do Construcionismo Social que consideram o selfcomo sendo construído em narrativas interacionais de acordo com os recursos culturais disponíveis. Para ele, o que os pensadores desta perspectiva invocam é o velho e familiar self da Filosofia Humanista. Um self que é $\mathrm{o}$ ator que interage com outros em um contexto cultural e lingüístico, que é onde os efeitos de sentido e comunicação assumem sua forma, acompanhados de todos os pressupostos que afirmam a singularidade e o caráter cumulativo do tempo vivido da consciência.

Não só é o mesmo self da Filosofia Humanista, como se trata também do mesmo self da Hermenêutica e da Fenomenologia, aponta Rose. Self que é agora postulado como a solução para o problema de como poderia, ele próprio, constituir uma possibilidade. O principal argumento dele é que as análises feitas sob os pressupostos do Construcionismo Social são problemáticas por causa da visão de linguagem que defendem. Linguagem que é vista como uma fala constituída de significados situacionalmente negociados entre indivíduos.

\footnotetext{
1 O pronome "eu" e a palavra "self" serão utilizados neste ensaio como sinônimos.
} 
Para o autor, as análises construcionistas, ao verem linguagem como fala, seguem o modelo banal $^{2}$ da comunicação, onde as pessoas utilizam vários recursos lingüísticos para construir mensagens que transmitem as suas intenções. A conseqüência, para Rose, é que estes trabalhos colocam o agente humano como o núcleo dessas atividades de produção de sentido para ter uma vida significativa. O ser humano, então, é mostrado como aquele que se constrói a si próprio como um self ao dar à sua vida a coerência de uma narrativa.

Rose critica que o self, apenas por ser capaz de se narrar a si próprio de várias maneiras, é reinvocado como um exterior inerentemente unificado com essas comunicações. Para ele, isso faz lembrar a observação de Nietzsche (1992) de que um pensamento vem quando quer e não quando a pessoa quer. Rose defende, então, que se questione toda a tirania da linguagem, da comunicação, do significado, que são invocados pelas Ciências Sociais com a intenção de se distinguirem das Ciências Naturais, devido à natureza especial do seu objeto.

A proposta de Rose é que para explicar nossa história e nossa especificidade não devemos nos voltar para os signos, os significados e as comunicações, mas para a análise das técnicas, das intensidades, das autoridades e dos aparatos. Em vez de ver a linguagem como comunicação, vê-la como agenciamento. A construção discursiva do self deve ser feita de uma forma diferente, o interesse é ver "quem fala, de acordo com que critérios de verdade, de quais lugares, em quais relações, agindo sob quais formas, sustentado por quais hábitos e rotinas, autorizado sob quais formas, em quais espaços e lugares, e sob que formas de persuasão, sanção, mentiras e crueldades?" (Rose, 2001, p. 158).

Não é o caso de dar as costas para a linguagem ou para todos os estudos sobre discurso, ressalta Rose, mas sim sugerir que essas análises são mais produtivas quando se focalizam não no que a linguagem significa, mas no que ela faz. As análises da linguagem que primam pela questão do significado concedem uma excessiva autonomia à semântica e à sintática, dando pouca atenção às práticas situadas que provocam certas relações da pessoa consigo mesma. Elas ignoram os aparatos, como livros infantis, gráficos, vitrais, televisão, que são tecnologias culturais que funcionam como formas de codificar, estabilizar e intimar as pessoas e não estão localizados em indivíduos particulares, nem são intercambiados de acordo com o modelo da comunicação.

Para Rose, não se trata, então, de um self que emerge por meio da narrativa de histórias, mas sim de primeiro fazer uma análise do agenciamento de sujeitos. A subjetivação não seria um produto nem da psique nem da linguagem, mas de um agenciamento heterogêneo de corpos, vocabulários, julgamentos, técnicas, inscrições e práticas. Por isso, defende que todos os efeitos da interioridade psicológica são constituídos por meio da ligação dos humanos a outros objetos e práticas, multiplicidades e forças. São justamente essas variadas relações e ligações que produzem o sujeito como um agenciamento.

Deleuze e Guattari (1995/1997) são citados por Rose para mostrar que uma forma melhor de ver os sujeitos é como agenciamentos que metamorfoseiam ou mudam suas características à medida que expandem suas conexões. As pessoas seriam, então, as cambiantes conexões com as quais elas são associadas. Rose credita uma importância particular à Psicologia em relação aos agenciamentos contemporâneos de subjetivação. Isso porque os saberes e as autoridades psi têm gerado técnicas para moldar e reformar os eus, reunidas em um agenciamento, como os aparatos dos exércitos, das prisões, das salas de aula, das clínicas e outros.

O resultado é que as disciplinas psi estabeleceram uma variedade de racionalidades práticas, normas e dispositivos que servem para tornar inteligíveis e julgáveis as capacidades e a conduta dos humanos. Essas racionalidades práticas são regimes de pensamento, onde as pessoas podem dar importância a aspectos de si mesmas e à sua experiência, e regimes de prática, onde podem fazer de si mesmos seres éticos e dotados de agência, definidos de modos particulares, como pais, professores, amantes, e por meio de sua associação com vários dispositivos, técnicas, pessoas e objetos.

\footnotetext{
2 Rose não define em seu texto o que entende por modelo banal da comunicação, mas pela leitura de seu escrito podemos deduzir que ele está se referindo ao modelo emissor, mensagem, receptor e feedback.
} 
Ainda sobre a questão da linguagem, Rose afirma que o trabalho do lingüista francês Émile Benveniste não pode ser colocado no mesmo campo hermenêutico dos construcionistas sociais. Vai ser Benveniste, na opinião de Rose, quem apresenta um argumento diferente às propriedades subjetivantes da linguagem, pois enfatiza a capacidade de criação de sujeito que têm os pronomes pessoais. O argumento de Benveniste (1971) é que o pronome pessoal eu, como sujeito de enunciação, forma um locus de subjetivação, criando uma posição de sujeito, um lugar no interior do qual um sujeito pode surgir. Para este autor, é por meio da linguagem que os humanos se constituem a si próprios como sujeitos, porque é apenas a linguagem que pode estabelecer a capacidade de a pessoa se colocar como um sujeito. A subjetividade "é apenas a emergência, no ser, de uma propriedade fundamental da linguagem" (Benveniste, 1971, p. 224).

Rose acrescenta que a linguagem tanto torna possível que cada pessoa se estabeleça a si mesmo como um sujeito, ao se referir a si próprio como eu em seu discurso, quanto é tornada possível por esse mesmo fato. Os pronomes seriam signos vazios que se tornam plenos quando os falantes introduzem a si mesmos em uma instância de discurso. Por isso, Rose apóia o pensamento de Coward \& Ellis (1977) que defendem que é por isso que o lugar do sujeito tem que ser constantemente reaberto, pois não existe qualquer sujeito por detrás do eu que é posicionado e capacitado para se identificar a si mesmo naquele discurso.

A ênfase nas propriedades subjetivantes da linguagem, no entanto, é insuficiente para Rose, pois a subjetividade nunca pode ser uma operação puramente lingüística. Ele se une a Deleuze e Guattari (1995/1997) para defender que a subjetividade surge de um regime de signos e não de uma condição interna à linguagem, sendo que este regime de signos está sempre preso a um agenciamento ou a uma organização de poder. Nesta perspectiva, a subjetivação deve referir-se, antes de tudo, àquilo que Deleuze e Guatari (1995/ 1997) chamam, seguindo Foucault (1986), de um "agenciamento de enunciação".

Foucault (1986) propõe o termo "modalidades enunciativas" para conceituar as formas sob as quais a linguagem aparece em espaços e épocas particulares, formas que são irredutíveis às categorias lingüísticas. Trata-se dos diversos status, dos diversos lugares, das diversas posições que devem ser ocupadas em regimes particulares para que algo possa ser dito, ouvido e utilizado, como, por exemplo, o cientista, o terapeuta, o amante. Estas enunciações, então, não são colocadas em discurso por meio de uma função unificante de um sujeito e também não produzem esse sujeito como uma conseqüência de seus efeitos.

Deleuze e Guatari (1995/1997) explicam que, neste caso, as relações entre os signos são sempre reunidas no interior de outras relações. $\mathrm{O}$ agenciamento só é enunciação, só formaliza a expressão, em uma de suas faces. $\mathrm{Na}$ sua outra face, ele formaliza os conteúdos, este seria o agenciamento de corpo e é inseparável do outro. Dessa forma, Rose acrescenta que a linguagem, mesmo na forma de fala, aparece como um agenciamento de práticas discursivas. Isso seria diferente da perspectiva construcionista onde o self seria realmente constituído no interior da fala.

Rose argumenta que a linguagem é entendida, pelos construcionistas, como um complexo de narrativas do self que nossa cultura torna disponível. A subjetividade e as crenças sobre os atributos do self são propriedades não de mecanismos mentais, mas de conversas. Esta perspectiva exigiria uma análise mais dialógica, servindo como uma espécie de crítica de certas formas de falar o self. Citando Shotter (1989), Rose afirma que a análise toma a forma de uma espécie de etnografia interacional das formas de falas que são utilizadas pelas pessoas nas suas interações sociais e que utilizam para construir a si mesmas por meio do gerenciamento do sentido.

O caráter dialógico das autonarrativas, fazendo delas sociais e não individuais, foi o que acabou por se destacar, sendo o social entendido aqui como interpessoal e interacional. Rose cita Gergen \& Gergen (1988) para explicar que mesmo o objeto da autonarrativa seja um só eu, é um engano ver essas construções como o produto ou a propriedade de selves isolados. As pessoas, ao compreenderem as relações entre os fatos da vida, apóiam-se no discurso que nasce da troca social e que implica uma audiência. Para Rose, trata-se de uma socialidade que é reforçada pelas formas e respostas relacionais que certos modos de falar sobre o self recebem em trocas contínuas entre as pessoas. 
Esta perspectiva construcionista, para Rose, apreende algo de importante que é o fato de que se a subjetivação é analisada em termos das relações dos humanos consigo mesmos, o vocabulário discursivo exerce um papel importante na composição e recomposição dessas relações. Mas, para ele, estas análises continuam problemáticas pela visão de linguagem somente como fala e pelo self que interage com outros em um contexto cultural e lingüístico ser o mesmo self da Filosofia Humanista, da Hermenêutica e da Fenomenologia. Rose se interessará, então, pelas almas dobradas.

\section{OS DOBRAMENTOS PSI}

As reflexões de Deleuze (1992a, 1992b e 1988) sobre uma Filosofia da Dobra são utilizadas por Rose (2001) para afirmar que se vivemos nossas vidas como sujeitos psicológicos como sendo a origem de nossas ações, se colocamos nós próprios como sujeitos com certa ontologia, uma vontade de ser, isso se deve às formas pelas quais relações particulares do exterior têm sido dobradas, invaginadas, para formar um lado de dentro ao qual um lado de fora deve sempre fazer referência. A dobra descreve uma figura na qual o lado de dentro, o subjetivo, é não mais que um momento, ou uma série de momentos, por meio do qual uma profundidade foi constituída no ser humano.

Esse dobramento que produz os efeitos de subjetivação não é algo passivo, mas sim criado apenas ao ser praticado, ao se envolver com as técnicas de governo do corpo e de controle da dieta, com as técnicas de sexualidade e outros. Sendo assim, o humano não é nem um ator dotado de agência, nem um produto passivo de forças culturais. A agência é produzida no curso das práticas, sob toda uma variedade de restrições e relações de forças. A agência de cada um é, então, a resultante da ontologia que nós dobramos sobre nós mesmos durante a nossa história e nossas práticas. O que é dobrado é sempre alguma força, composta de qualquer coisa que possa adquirir o status de autoridade em um agenciamento particular.

Rose vai se interessar em como Deleuze (1988) explica os quatro eixos pelos quais Foucault analisa as tecnologias éticas por meio do conceito de dobramento:
1) o primeiro eixo diz respeito aos aspectos do ser humano que devem ser circundados e dobrados: o corpo, seus prazeres e desejos;

2) o segundo eixo fala da regra de acordo com a qual a relação entre forças se torna uma relação consigo mesma. A regra, que pode ser entre outras natural, divina, racional, está sempre associada com uma autoridade particular, como, por exemplo, o padre, o intelectual, o artista;

3) o terceiro eixo é o da dobra da verdade que surge do fato de que cada relação consigo mesma está organizada sobre o eixo da subjetivação do saber e, por conseqüência, da relação de nosso ser com a verdade, seja ela teológica, filosófica ou psicológica;

4) o quarto eixo é a dobra da esperança, da imortalidade, da eternidade, da salvação, da liberdade, da morte ou da separação.

Rose define o seu trabalho atual como a tentativa de responder à seguinte questão de Deleuze (1991, p. 112): "E o que dizer, de nossos próprios modos atuais, da moderna relação consigo? Quais são as nossas quatro dobras?" As suas primeiras reflexões tem sido a respeito do papel que as psicociências e as psicotécnicas exercem nesses quatro dobramentos. Para isso, ele vai esboçar algumas das características desses dobramentos psi.

A primeira característica é que o aspecto do ser humano que é circundado e dobrado nos agenciamentos contemporâneos de subjetivação não é nem o corpo/prazer nem a carne/desejo, mas o eu/realização. Rose afirma que passamos a ser habitados por uma ontologia psi, por uma inescapável interioridade que escava um universo psíquico com uma topografia que tem suas próprias características. A ontologia humana é estabelecida por meio de conexões constitutivas com as tecnologias psi que a imaginam e que agem sobre ela.

O trabalho de Michel Taussig (1993) sobre mimese é lembrado por Rose, porque as conexões constitutivas dessa ontologia humana ativam algo que o primeiro autor analisou: o devir colocado em ação na contínua interação 
entre a cópia e aquilo que é copiado. Para Rose, para ser o eu que a gente é, a gente não deve ser o eu que a gente não é, por isso o tornar-se eu é um copiar recorrente que tanto emula outros eus quanto difere deles. $O$ autor defende que, na contemporaneidade, as características pertinentes da mimese e da alteridade são dispostas nos vetores dos estilos-de-vida, das sexualidades, das personalidades e das aspirações.

A ontologia psi em humanos, para Rose, está ligada aos processos que escavam um interior por meio do dobramento dos componentes psi que têm sido distribuídos por meio desses aparatos e dessas tecnologias, sendo que um ponto-chave da dobra da autoridade é a questão terapêutica, não no sentido de um privilégio concedido à psicoterapia, mas no sentido de que a relação consigo mesmo é dobrada em termos terapêuticos. Isso ocorre quando pensamos em nós mesmos a partir dos valores da normalidade e da patologia, diagnosticando nossos prazeres e desgraças em termos psi. É essa relação terapêutica conosco mesmos e os componentes considerados autorizados dessa relação que têm se multiplicado em nosso presente.

Rose mostra que as práticas contemporâneas de subjetivação colocam em jogo um ser que deve ser anexado a um projeto de identidade e a um projeto de estilo-de-vida, no qual a vida adquire sentido na medida em que pode ser construída como o produto da escolha pessoal. $\mathrm{O}$ autor afirma que seria tolo afirmar que a Psicologia é a origem de todas essas máquinas de subjetivação. Para ele, trata-se de uma questão de como os agenciamentos de paixão e prazer, de trabalho e consumo, de guerra e esporte, de estética e tecnologia, têm dado aos seus sujeitos uma forma psicológica.

Uma das características mais esperançosas, para Rose, da atual topografia ética, é a heterogeneidade do território mapeado pelas maquinações do eu. Este território ético, no entanto, não é um espaço livre, pois as relações das pessoas consigo mesmas são estabilizadas em agenciamentos que variam de setor para setor. São diferentes tecnologias que dependem da identificação da pessoa, como, por exemplo, se homem ou mulher, se rico ou pobre, se branco ou negro e que operam sob diferentes formas de autoridade. Por isso, novos modos de subjetivação produzem novos modos de exclusão e novas práticas para reformar as pessoas que estão excluídas.
Além de enfatizar a heterogeneidade dos dobramentos que agenciam as relações contemporâneas conosco mesmos, Rose também argumenta que elas operam de acordo com um diagrama comum, partilhado. Este diagrama é a positividade aberta por nossos regimes contemporâneos de subjetivação, trazida à existência pelo saber e pelas práticas das Ciências Humanas. Para o autor, estas ciências estabelecem para elas mesmas o próprio império que elas iriam mapear, colonizar, povoar e conectar pelas redes de pensamento e ações.

Parafraseando Foucault (1985), Rose afirma que é diagramado um ser que, do interior dos discursos que o rodeiam e das práticas pelas quais ele é agenciado, é capacitado a saber aquilo que está em sua positividade. Ou seja, um ser que pensa si mesmo tanto como livre quanto como determinado pelas positividades essenciais a si mesmo, pois delimita a possibilidade de suas práticas de liberdade no mesmo momento em que concede a essas positividades o status de verdade.

Rose conclui seu pensamento afirmando que é esse ser, cuja invenção é tão recente e fundamental à nossa experiência contemporânea, que buscamos hoje governar sob o ideal da liberdade. Um ideal que impõe tantas cargas, ansiedades e divisões, ao mesmo tempo em que inspira projetos de emancipação e pelo qual autorizamos inúmeras autoridades para nos ajudar no projeto de sermos livres de qualquer autoridade menos a nossa própria. Para o autor, chegou o momento de distinguir as rachaduras desse espaço de interioridade que já foi o nosso porto seguro, possibilitando que, mesmo que não consigamos desinventar a nós mesmos, possamos ao menos reforçar a questionabilidade das formas de ser que têm sido inventadas para nós e iniciar a invenção de nós mesmos de forma diferente.

\section{LINGUAGEM COMO NARRATIVA}

Assim com Rose, Bruner também apresenta uma concepção de self diferente da Filosofia Humanista, da Hermenêutica e da Fenomenologia e o seu conceito de self transacional vai estar diretamente relacionado à linguagem como narrativa. Antes de aprofundarmos estas questões, no entanto, é preciso fazer algumas considerações ao fato de Bruner ser utilizado 
tanto por pensadores do Construcionismo Social quanto do Construtivismo ${ }^{3}$. Mesmo com o uso de termos diferenciados para estas duas perspectivas, não há garantia de se estabelecer uma fronteira clara e definitiva sobre elas.

Huitt (2003), por exemplo, ao falar do construtivismo na área da Educação, afirma que John Dewey é com freqüência citado como o fundador filosófico desta visão, sendo Ausubel, Bruner e Piaget considerados os chefes teóricos entre os cognitivos construcionistas, enquanto Vygotsky é o maior teórico entre os construtivistas sociais. Como podemos ver, Bruner aparece ao lado de Piaget como um expoente do construtivismo, sendo que suas idéias na área da educação foram publicadas no Brasil no livro $A$ Cultura da Educação (2001).

Em outro livro, Realidade Mental, Mundos Possiveis (1997b), Bruner se define como um construtivista convicto, por acreditar que da mesma forma que construímos ou constituímos o mundo, acredita também que o self é uma construção, um resultado de ação e simbolização. Num primeiro momento, chegar à conclusão de que Bruner é um construtivista e não um construcionista social parece ser uma obviedade. Mas esta questão não é tão fácil assim. Isso porque autores do Construcionismo Social consideram Bruner como também pertencendo a esta perspectiva teórica.

Iñiguez (2002), por exemplo, relaciona uma série de autores, entre eles Bruner, que podem ser considerados pertencendo ao Construcionismo Social, mesmo que alguns deles não se definam como parte desta corrente, porque seus aportes teóricos são inteiramente construcionistas. Íñiguez destaca que Bruner tem um grande prestígio na academia e é reconhecido como um dos mais importantes psicólogos da história, assim como Piaget, Freud e Vigotski. Os aportes que aproximariam Bruner do Construcionismo Social estão, principalmente, em seu livro Atos de Significação (1997a). Para Íñiguez, nesta obra está presente a mais dura crítica ao Behaviorismo e ao Cognitivismo produzida na Psicologia. Nela, há a proposição do significado como centro psicológico e a ênfase na importância da narrativa da vida social, tanto no contexto da aquisição da linguagem quanto na natureza do self.

O que define a narratividade, para Bruner, não é a ordem do que se conta, mas o fato de não precisar de uma referência externa. Não há necessidade de se referir a algo fora da narração, seu sentido está na própria narração. A decisão da linguagem é um exemplo desse tipo de narração. As crianças aprendem a falar instrumentalmente, porque vêem que dizer algo tem conseqüências e, com a ajuda das pessoas ao seu redor, vão construindo narrativas. Assim, a criança aprende que falar cria efeitos e os explica. Para Íñiguez, estas idéias de Bruner são coerentes com as características do Construcionismo Social de que a linguagem é ação e criadora de conseqüências na interação e a importância dos contextos sociais na ação social. Por isso, acredita que Bruner é um dos autores construcionistas que mais deveriam ser considerados, mesmo que o próprio não se defina como um. Independente de ser considerado construtivista, construcionistas social ou ambos, o importante é ver onde Bruner se posiciona dentro dos estudos sobre narrativa.

No início de sua última obra, Making Stories: Law, Literature, Life (2002), ainda não traduzida para o português, Bruner pergunta se nós realmente precisamos de mais um livro sobre narrativa. Ele acredita que sim e, antes de apresentar as suas últimas pesquisas sobre o tema, leva o leitor para uma viagem pelos estudos sobre narrativa. Bruner (2002) afirma que na Antiguidade há uma escassa bibliografia sobre a natureza, os usos e o domínio da narrativa que começa seriamente com Aristóteles, em Poética (século 4 a.C.). A sua preocupação era principalmente com a maneira pela qual a literatura imitava a vida, por meio do conceito de mimesis. Já a sabedoria Medieval nunca teve uma preocupação central sobre estas questões e o florescimento do racionalismo na Renascença e o Iluminismo empurraram os estudos sobre narrativa para o fundo do palco das atenções.

Foi Vladimir Propp que, na Rússia, após a revolução neste país, em 1917, trouxe a preocupação com a narrativa de volta à luz. Propp era

\footnotetext{
3 Como afirmam Wortmann e Veiga-Neto (2001), quando nos referimos ao Construcionismo Social, prefere-se utilizar o termo construcionismo ao invés de construtivismo, que é a expressão mais empregada nas línguas inglesa e espanhola para se referirem a esta temática. A intenção é evitar confusões com a associação de tal termo às teorias construtivistas sobre a inteligência, principalmente as teorizações de Jean Piaget, que são tão populares no Brasil. Esta será opção adotada neste ensaio também.
} 
um folclorista que foi extremamente influenciado pelos novos lingüistas formalistas russos (Vitor Sklovski, Yury Tynyanov, Boris Eichenbaum, Roman Jakobson e Grigory Vinokur), apesar de ele ser suficientemente humanista para reconhecer que a estrutura da forma das histórias não era apenas uma questão de sintaxe, mas também refletia o esforço humano de enfrentar o desagradável e o inesperado da vida. Ele pesquisava componentes e estruturas universais dos contos populares russos, no mesmo espírito dos lingüistas da sua época que pesquisavam gramáticas universais. Para Bruner, Propp merece o crédito de ter começado os estudos modernos sobre narrativa.

O erudito e crítico literário Kenneth Burke revisitou o pensamento de Aristóteles em seu livro A Grammar of Motives (1945), com o principal interesse de estudar as condições necessárias para se retratar um drama. Ele considerava a narrativa dramática um reflexo da nossa habilidade de copiar os problemas humanos, mas o estruturalismo continuava dominando a cena pós-guerra. O antropólogo Claude Lévi-Strauss, por exemplo, adaptou a idéia de Propp da não variação das seqüências das histórias para reivindicar que os contos folclóricos e os mitos refletiam o contraste e o conflito binário das estruturas das culturas das quais pertenciam, ou seja, eram manifestações dos conflitos que ocorrem na vida em sociedade.

Os anos 60, com o surgimento da lingüística de Noam Chomsky, a revolução cognitiva e a inteligência artificial, não foram uma boa época para os estudos da narrativa nas Ciências Humanas. A questão das histórias e suas formas foram deixadas para a comunidade literária e para poucos historiadores. Mas existiram algumas exceções, porque os lingüistas sempre foram seduzidos pela poesia e as formas das histórias é um tema clássico na poesia. Inclusive um famoso lingüista dessa época, William Labov, publicou um clássico artigo sobre o assunto chamado Narrative Analysis (1967). Labov estava principalmente interessado na linguagem da narrativa, mas também se preocupou com os usos que eram feitos da narrativa. Assim como Aristóteles, ele viu nas narrativas a nossa maneira de fazer sentido com o desagradável e o inesperado da vida. Um sinal da renovação do interesse na narrativa nos últimos anos foi a republicação com comentários do artigo de Lavov, em 1997, no Journal of Narrative and Life History.
O interesse na narrativa cresceu firmemente nas últimas duas décadas, principalmente, no poder da forma das histórias em moldar nossa concepção de realidade e verdade. Houve inclusive, destaca Bruner, a virada narrativa (narrative turn), com os historiadores liderando o movimento, para contraporem-se a despersonalização sociológica e as interpretações marxistas do passado. No mundo da língua inglesa, a chamada virada narrativa na História veio de acadêmicos como Hayden White, Simon Schama, e Arthur Danto; na França, de historiadores da escola de Annales como Georges Duby e François Furet. Mas a virada narrativa afetou muitos outros campos do saber.

O estudo de autobiografias também seguiu o movimento da virada narrativa, não só como uma descrição das vidas de uma época, mas também como uma expressão da condição humana numa circunstância particular da história. Logo, conhecidos críticos literários como William Spengemann e James Olney, nos Estados Unidos, e Philippe Lejeune, na França, começaram a explorar autobiografias como uma forma de construção de self em resposta a épocas históricas e circunstâncias pessoais. Inclusive antropólogos desviaram seu olhar para as vidas narradas para entender como uma pessoa torna-se um Zuni ou um Kwakiutl.

Uma nova Antropologia, particularmente a Antropologia americana, e possivelmente em protesto ao impessoal estruturalismo de LévisStrauss, tornou-se preocupada com cultura e personalidade, com uma ênfase mais na pessoalidade do que no institucional. Com o tempo, autores como Bronislaw Malinowski, Margaret Mead e Ruth Benedict tornaram-se conhecidos, focando suas pesquisas em questões como as pessoas criam significados dentro de sua cultura. A Antropologia deles não era apenas sobre instituições, mas sobre pessoas vivendo suas vidas. Eles contavam histórias sobre as histórias que as pessoas contavam a eles, tornando a Antropologia interpretativa.

Em 1981, W. J. T. Mitchell editou um livro chamado On Narrative, uma coleção de artigos de historiadores, psicoanalistas, filósofos e críticos literários, todos falando sobre a virada narrativa. Bruner enfatiza que os estudos sobre a narrativa tornaram-se um campo próprio, com suas características, seus usos e sua importância, espalhando-se além dos limites da academia. A narrativa tornou-se quase simbólica, um 
instrumento para os oprimidos lutarem contra a hegemonia da elite e seus especialistas, a maneira particular de cada um contar a sua história como mulher, como étnico, como desapropriado. A popularidade da narrativa acabou refletindo-se também nas novas políticas de identidade.

Bruner ressalta que o campo para os estudos da narrativa ainda está em construção. $\mathrm{O}$ seu trabalho no final dos anos 80 e início dos 90 focou-se na narrativa, na autobiografia e na construção do self. Desde o final dos anos 90 até os dias atuais, está pesquisando a narrativa e o Direito. Agora, Bruner, além de ser um pesquisador da Faculdade de Psicologia da New York University, é pesquisador da Faculdade de Direito da universidade, onde juntamente com Carol Feldman, pesquisa histórias legais, que são as histórias contadas antes dos julgamentos. Por isso, os estudos da narrativa continuam um campo de estudos em aberto, abrangendo um número amplo de diferentes e, em alguns casos, conflitantes teorias. Diferentes maneiras de estudar a narrativa convivem juntas, algumas vezes em projetos paralelos e em outras vezes inclusive indo uma contra a outra.

Brockmeier e Harré, no artigo Narrativa: problemas e promessas de um paradigma alternativo (2003), fazem uma tentativa de trazer os aspectos comuns aos trabalhos da virada narrativa. Para esses autores, estas pesquisas não só postularam um novo objeto de investigação, como as histórias que as crianças contam, discussões em festas, relatos de doença, autobiografias e retóricas da ciência, mas também uma nova abordagem teórica, um novo gênero de Filosofia da Ciência. O crescimento do interesse pelos estudos em narrativa sugere a emergência de um outro caminho para o movimento dos "novos paradigmas". Os trabalhos da virada narrativa são investigações interpretativas que se concentram nas formas de vida social, discursiva e cultural, em oposição à busca por leis do comportamento.

Os trabalhos da virada narrativa diferenciam-se de outras abordagens do tema, para Brockmeier e Harré (2003), apontando duas falácias nas análises narratológicas de outras perspectivas. A primeira é a falácia ontológica que aparece na crença de que realmente existe ali uma história, esperando para ser descoberta, independente da construção analítica e do processo narrativo fundamental. A segunda é a falácia representacional que está presente na concepção de uma única subjacente e verdadeira realidade humana a ser representada pela descrição narrativa.

Além disso, as formas narrativas não existem como padrões a serem concretizados. No entanto, elas assumem as formas exigidas pela situação em que ocorrem. Por isso, Brockmeier e Harré (2003) sugerem que as narrações não devem ser concebidas como entidades cognitivas, lingüísticas, metaligüísticas ou ontológicas, mas sim consideradas como modus operandi de práticas específicas de discurso. Para estudar a narrativa, é preciso, então, examinar tais práticas discursivas, seus textos culturais e seus contextos. Após vermos como Bruner se situa dentro da virada narrativa, vamos nos aprofundar nas suas idéias na relação do self com a narrativa.

\section{O SELF TRANSACIONAL E A NARRATIVA}

Bruner (1997a) vai propor a troca da idéia de um self essencial para uma noção de self conceitual e, posteriormente, defini-lo como um self transacional. Isso ocorre porque, para este autor, self está ligado diretamente à narrativa e à cultura, uma vez que mesmo as histórias mais simples dependem para serem construídas de um self como um protagonista com seus objetivos que operam em um contexto cultural (Bruner, 2001). Vai ser a nossa sensibilidade à narrativa a principal ligação entre nosso próprio sentido de self e nosso sentido de outros no mundo social a nossa volta. Sendo assim, a moeda comum entre estes sentidos será as formas de narrativa que a cultura nos oferecer.

O self é considerado transacional, para Bruner (1997a), porque é um relacionamento entre um locutor e um Outro Generalizado. O self se constitui como sendo um meio de estruturar nossos pensamentos e funciona para projetá-los tanto para o receptor do nosso discurso quanto para propósitos intrapsíquicos. Para o autor, o self transacional é uma construção que procede tanto de fora para dentro quanto de dentro para fora, tanto da cultura para a mente quanto da mente para a cultura. Ou seja, não há mais como saber o que é de dentro e o que é de fora.

Em seu último livro, Bruner (2002) esclarece ainda mais esta questão. Para ele, a construção do self, falando de uma maneira cartesiana 
errada, é tanto de dentro quanto de fora. De dentro é memória, sentimentos, idéias, crenças e subjetividade, mas muito da construção do selfé de fora, baseado na estima dos outros e pelas muitas expectativas que desde cedo nós, mesmo sem prestar atenção, apanhamos da cultura na qual estamos imersos.

Bruner (1997b) conta que sempre tentou evitar conceitos como self, usando termos como "rotinas de execução", "circuitos recursivos" e "estratégias de reparo de enunciados". Por isso, afirma que a sua discussão sobre self transacional é uma tentativa de virar uma nova página. Isso porque, para ele, de uma maneira inevitável, a reflexão implica um agente reflexivo. A metacognição requer uma rotina normatizadora que sabe como e quando fugir do processamento puro para procedimentos de processamento corretivo. A criação de cultura do tipo negociável do qual fala envolve um participante ativo, mas isso é diferente do self do Humanismo. Como devemos tratar, então, do self?

Para Bruner (1997b), o self é uma construção, um resultado de ação e simbolização. Pensa o self como um texto sobre como alguém está situado em relação aos outros e em relação ao mundo. A interpretação deste texto por um indivíduo é seu sentido de self naquela situação, sendo que ele é composto de expectativas, sentimentos de estima e poder, etc. Por fim, o self de Bruner se afasta do self do Humanismo por não ser essencialista. Bruner (2002) pergunta se há algum tipo de self essência dentro de nós, que, de certo modo, está apenas ali? Ele responde, primeiramente, com uma outra pergunta: se fosse assim, por que nós sempre precisamos falar a nós mesmos sobre nós mesmos, e por que há injunções como "conhecer a ti mesmo" ou "ter o seu próprio self verdadeiro?"

Se nossos selves estivessem apenas lá, para Bruner, certamente, nós não teríamos a necessidade de contar as nós mesmos sobre eles. Mas nós passamos boa parte do nosso tempo fazendo justamente isso, seja sozinho, ou com amigos, ou de forma indireta no psiquiatra, ou nos confessando se somos católicos. Bruner termina a resposta, diferenciando o seu conceito de self do essencialista self do Humanismo, propondo corajosamente, segundo suas próprias palavras, que não existe algo como um intuitivamente óbvio e essencial self para conhecer, um que esteja lá pronto para ser retratado em palavras.
Nós constantemente construímos e reconstruímos nossos selves para irem ao encontro das necessidades das situações que nós encontramos, e nós fazemos isso com a ajuda de nossas memórias do passado e nossas esperanças e medos para o futuro. Para Bruner, falar de nós mesmos para nós mesmos é como construir uma história sobre como e o que nós somos, sobre o que está acontecendo, e sobre por que nós estamos fazendo o que estamos fazendo. Isso não significa que tenhamos que criar essas histórias do zero cada vez. Nossas histórias vão se acumulando com o passar do tempo, inclusive tomando formas e padrões de gêneros convencionais.

Nossas histórias acabam perdendo a validade, e não apenas porque nós envelhecemos e amadurecemos, mas porque nosso processo de construir histórias precisa se ajustar a novas circunstâncias, novas amizades, novas iniciativas. Nossas memórias acabam sendo vítimas de nossa própria maneira de criar histórias. Isso não quer dizer que eu não posso contar a alguém, ou a mim mesmo, a "original, verdadeira história" sobre minha desolação no verão em que meu pai morreu. Eu estarei contando a alguém, ou a mim mesmo, uma nova história sobre um tempo 12 anos mais velho. E eu poderei contar essa história inúmeras vezes, todas elas construídas tanto pelos fatos que aconteceram na minha desde aquele fato, quanto pelas circunstâncias daquele verão passado.

Os trabalhos na perspectiva da virada narrativa impõem duas exigências intimamente relacionadas com o estudo do self (Brockmeier e Harré, 2003). Uma delas é que as investigações devem focalizar os significados em que o self é definido tanto pelo indivíduo como pela cultura na qual ele participa. Bruner (1997a) ressalta, no entanto, que isso não é suficiente para entender como um selfé negociado, pois o selfnão é simples resultado da reflexão contemplativa. Por isso, a segunda exigência está em sintonia com as práticas nas quais os significados do self são atingidos e colocados em uso. São estas exigências que nos oferecem uma visão mais descentralizada do self. Para obtermos uma noção geral de um self particular na prática, para Bruner (1997b), devemos mostrar seus usos em uma variedade de contextos culturais específicos e isto acontece por meio da narrativa das pessoas. 


\section{CONSIDERAÇÕES FINAIS}

Tanto Rose quanto Bruner propõem conceitos de self diferentes do essencialismo do Humanismo, da Hermenêutica e da Fenomenologia a partir de visões diferentes de linguagem. Rose vai propor a linguagem como agenciamento, onde a subjetivação não seria o resultado nem da psique nem da linguagem, mas de um agenciamento heterogêneo de corpos, vocabulários, julgamentos, técnicas, inscrições e práticas. Os efeitos da interioridade psicológica são constituídos por meio da ligação dos humanos a outros objetos e práticas, multiplicidades e forças, sendo que são essas variadas relações e ligações que produzem o sujeito como um agenciamento.

A partir das reflexões de Deleuze sobre uma Filosofia da Dobra, Rose vai propor que o humano não é nem um ator dotado de agência, nem um produto passivo de forças culturais. A agência é produzida no curso das práticas, sob toda uma variedade de restrições e relações de forças. Por isso, a agência de cada um é a resultante da ontologia que nós dobramos sobre nós mesmos durante a nossa história e nossas práticas. O que é dobrado é sempre alguma força, composta de qualquer coisa que possa adquirir o status de autoridade em um agenciamento particular.

Os trabalhos da virada narrativa irão se diferenciar de outras abordagens do tema, mostrando duas falácias nas análises narratológicas de outras perspectivas: a falácia ontológica (a existência de uma história, esperando para ser descoberta, independente da construção analítica e do processo narrativo fundamental) e a falácia representacional (concepção de uma única subjacente e verdadeira realidade humana a ser representada pela descrição narrativa). As formas narrativas não existem como padrões a serem concretizados, mas assumem as formas exigidas pela situação em que ocorrem.

Brockmeier e Harré (2003) sugerem, então, que as narrações não devem ser concebidas como entidades cognitivas, lingüísticas, metaligüísticas ou ontológicas, mas sim consideradas como modus operandi de práticas específicas de discurso. O conceito de self de Bruner vai estar diretamente ligado à questão da narrativa, porque as histórias dependem para serem construídas de um selfcomo um protagonista com seus objetivos que operam em um contexto social. O self será transacional, pois é um relacionamento entre um locutor e um Outro Generalizado. O uso ainda da palavra self é justificada pelo autor, porque a reflexão implica um agente reflexivo, mas não existe algo como um essencial self para conhecer, um que esteja lá pronto para ser retratado em palavras.

Sendo assim, Rose, utilizando a linguagem como agenciamento e o conceito de dobra, e Bruner, com a visão da linguagem como narrativa e concepção de selftransacional, procuram diferenciar suas idéias das propriedades subjetivantes da linguagem, evitando que a subjetividade seja considerada apenas uma operação lingüística. Propriedades subjetivantes da linguagem que são usadas por outras teorias para defender um self essencialista constituído no interior da fala, onde o agente humano seria o núcleo dessas atividades de produção de sentido.

No entanto, esse self que surge das propriedades subjetivantes da linguagem não deve ser totalmente descartado, porque nós também somos subjetivados por ele. A importância de outras visões de linguagem e self, como as de Rose e Bruner, está principalmente em mostrar que estas questões da subjetividade não são apenas questões internas da linguagem e que, portanto, a reinvenção de nós mesmos não é só uma questão de semântica e sintática. Por isso, propomos chamar esse self que emerge das propriedades subjetivantes da linguagem de self ficcional, diferenciando-o dos outros tipos de self, para que seja estudado como um discurso que nos subjetiva e não como um self essencialista.

\section{REFERÊNCIAS}

Aristóteles. (1981). Poética (séc. 4. A.C.). São Paulo: Edições de Ouro.

Benveniste, E. (1971). Problems in general linguistics. Miami: University of Miami Press.

Brockmeier, J., \& Harré, Rom. (2003). Narrativa: Problemas e promessas de um paradigma alternativo. Psicologia: Reflexão e Crítica, 16(3), 525-535.

Bruner, J. (1997a). Atos de significação. Porto Alegre: Artes Médicas. 
Bruner, J. (1997b). Realidade mental, mundos possíveis. Porto Alegre: Artes Médicas.

Bruner, J. (2001). A cultura da educação. Porto Alegre: Artmed.

Bruner, J. (2002). Making stories: Law, literature, life. Cambridge e Londres: Harvard University Press.

Burke, K. (1945). A grammar of motives. Nova York: Prentice-Hall.

Coward, R., \& Ellis, F. (1977). Language and materialism: Developments in semiology and the theory of subject. Londres: Routledge and Kegan Paul.

Deleuze, G. (1991). Foucault. São Paulo: Brasiliense.

Deleuze, G. (1992a). The fold: Leibniz and the baroque. Minneapolis: University of Minnesota Press.

Deleuze, G. (1992b). Expressionism in philosophy: Spinoza. Nova York: Zone Boosk.

Deleuze, G. (1998). Foucault. Minneapolis: University of Minnesota Press.

Deleuze, G., \& Guattari, F. (1995/1997). Mil platôs (Vols. 1-5). Rio: Editora 34.

Foucault, M. (1985). As palavras e as coisas: Uma arqueologia das ciências humanas. ( $3^{a}$ ed.). São Paulo: Martins Fontes.

Foucault, M. (1986). A arqueologia do saber (2a ed.). Rio: Forense-Universitária.

Gergen, K. J., \& Gergen, M. (1988). Narrative and the self as relationship. In L, Berkowitz. (Org.). Advances in experimental and social psychology (Vol. 21). Nova York: Academic Press.

Huitt, W. (2003). Constructivism. Educational psychology interactive. Valdosta: Valdosta State University. Acesso em 14 mai. 2007, disponível em: http://chiron.valdosta.edu/ whuitt/col/cogsys/construct.html
Íniguez, L. (2002). Construcionismo Social e Psicologia Social. In Martins, J. B., Hammouti, N. E., \& Íñiguez, L. (Eds.). Temas em análise institucional e construcionismo social (pp. 127-157). São Carlos: RIMA - Fundação Araucária.

Labov, W., \& Waletsky, J. (1967). Narrative Analysis. In Helm, J. (Ed.). Essays on the Verbal and Visual Arts (pp. 12-44). Seattle: University of Washington Press.

Mitchell, W. J. T. (1981). On Narrative. Chicago: University of Chicago Press.

Nietzsche, F. (1992). Além do bem e do mal: Prelúdio a uma filosofia do futuro. São Paulo: Cia. das Letras.

Rose, N. (2001). Inventando nossos eus. In T. T., Silva. (Org.). Nunca fomos humano: Nos rastros do sujeito (pp. 137-204). Belo Horizonte: Autêntica.

Shotter, J. (1989). Social accountability and self specification. In J., Shotter, \& K., Gergen. (Org.). Texts of identity. (pp.133-51) Londres: Sage.

Taussig, M. (1993). Mimesis and alterity: A particular history of the senses. Nova York: Routledge.

Wortmann, M. L. C., \& Veiga-Neto, A. (2001). Estudos culturais da ciência $\&$ educação. Belo Horizonte: Autêntica, 2001.

Recebido: 14/02/2008 Received: 02/14/2008

Aprovado: 03/03/2008 Approved: 03/03/2008 